\title{
Sports match official research: An evolving narrative, positioning future research
}

Tom Webb, School of Sport, Health and Exercise Science, University of Portsmouth

\begin{abstract}
The purpose of this article is to foster debate and discussion around the developing sport match official research area. To that end the literature in this field is examined and discussed with gaps in the research identified and explored. Areas of future research are discussed as pertinent areas for scholars to focus upon, with mental health, online abuse, gender studies and investigations into the treatment and support for young people who officiate particularly important. It is the intention of this commentary to encourage academics from sport research fields that have not traditionally considered match officials as an area of interest, and to motivate those from disciplines outside sport related enquiry to consider adapting and applying methods to this unique population, in order to continue the development of scholarly activity in this subject area. With match officials acting as facilitators of sport and physical activity for populations around the world, maximising the recruitment of match officials and retaining those match officials already in operation is essential to enable participation in sport and physical activity. Therefore, research in this subject area has arguably never been more important.
\end{abstract}

Keywords: match officials, referees, mental health, abuse, online abuse, workplace incivility.

\section{Introduction}

Research concerning match officials in sport has evolved considerably over the past 10-15 years. Historically, many publications focused predominantly on football (soccer), rather than other sports, and these publications were principally from a physiological or psychological (in the case of the United States) disciplinary perspective, or focused on the 
technical performance of the referee (Pina, Passos, Araújo, \& Maynard, 2018; Webb, 2017). Very few studies have considered football referees from a management, leadership or sociological perspective (Pina et al., 2018), with some notable recent exceptions (Cleland, O’Gorman, \& Webb, 2017; Dell, Gervis, \& Rhind, 2016; Webb, Cleland, \& O’Gorman, 2017; Webb, Wagstaff, Rayner, \& Thelwell, 2016). This observation can also be extrapolated to research related to match officials in other sports, although there are increasing examples of research into match officials in sports other than football, and some of this research has adopted a management or sociological theoretical stance (Jacobs, Tingle, Oja, \& Smith, 2020; Ridinger, Kim, Warner, \& Tingle, 2017a; Ridinger, Warner, Tingle, \& Kim, 2017b; Webb, Rayner, \& Thelwell, 2019).

Despite these developments in research focus, there are still a significant number of under researched areas in the extant sports match official literature. In order to further develop our understanding of the match official related subject area, the continued development of this future research is essential. Future research can and should enable those in positions of governance to develop match official related training and development programmes, guided by research findings. Moreover, the further development of the research area would enable greater understanding of the challenges that match officials face in their day to day pastimes or careers, at both mass participation and elite levels of sport. We know that the challenges faced by match officials can differ depending on the level at which they officiate (Webb, Rayner, Cleland, \& O'Gorman, in press), however we also know that there are some similarities between the difficulties faced at these different levels (Webb \& Gorczynski, in press).

Therefore, this commentary article examines the current status of the sport management and sport sociology related match official research and argues for the development of research into specific areas, addressing particular needs, requirements and 
gaps in the present research. The most pertinent gaps and areas with the most pressing need are focused upon, building on the existing research, in order to develop new lines of empirical enquiry.

\section{Research development}

As an evolving research area, studies involving match officials have historically tended to be from a natural science perspective, rather than a management or social science related subject discipline (Pina et al., 2018). However, research in the areas of management and social science is developing and these developments have occurred particularly over the past 10 years. Prior to this, monographs and papers tended to be historical in nature, with a number of these publications considering the evolution of a particular sport, or the behaviour of players and spectators as sports became more established in English society (Collins, 2009; Dunning \& Sheard, 2005; Holt, 1989; Malcolm, 2001; Taylor, 2008; Vamplew, 1988).

As a natural progression, research also began to focus on sociological developments in sport, and in football in particular. The evolution of the laws of the game and the pressure that these law changes had put on referees were considered, with research reflecting upon the development of the referee in football from a figurational sociology perspective, and the involvement of organisations such as FIFA and UEFA in the development of officiating (Colwell, 1999, 2000, 2001). This research developed and encouraged other contributions in related subject areas and disciplines, although there was a significant gap in the publication of Colwell's work and subsequent related publications, with the majority of the published research continuing to focus upon football referees.

\section{Abuse as an evolving narrative}

As research in the field of sports match officials continued to develop, there was a recognition amongst both researchers and individuals involved in sports governance and sport governing bodies, that there were concerns surrounding the abuse of match officials and the 
associated reduced recruitment and the discontinuation of these match officials. Governing bodies started to formally address the concerns related to the abuse of their match officials with policy interventions and public information campaigns. For example, the English Football Association (EFA) launched the Respect Programme in 2008, with the initiative designed to combat negative behaviour in and around the playing area and contribute to increased recruitment and retention of referees (The FA, 2008).

Other sports have also begun to address concerns around abuse with the Rugby Football Union (RFU) launching the 'keep your boots on' campaign aimed at coaches and match officials (RFU, n.d.). In countries other than England and the United Kingdom, other governing bodies have also seen the requirement to intervene in order to attempt to challenge negative behaviour towards match officials. For example, the Dutch FA, (KNVB) have introduced a phoneline for referees that suffer verbal or physical abuse, alongside a violence prevention initiative (KNVB, n.d., a; KNVB, n.d., b), and Hockey Australian Capital Territory (ACT) introduced a 'season of respect' designed to reduce the abuse that their umpires were receiving (Hockey ACT Umpire Handbook, 2013). Whereas in the U.S. some states have introduced laws with associated jail time for attacks against match officials. 21 states currently have officiating assault laws (19 with criminal laws and two with civil statutes), 16 states have limited liability legislation and 15 states have independent contractor laws (National Association of Sports Officials, 2019).

Academic research has shined a light on some of the issues to which governing bodies are reacting and also considered the impact of some of the initiatives that have been launched. The coverage of negative behaviour towards match officials in sport was predominantly psychological in nature prior to the 2000s (Anshel \& Weinberg, 1995; Goldsmith \& Williams, 1992; Rainey, 1994; Rainey, 1995; Rainey \& Cherilla, 1993; Rainey \& Hardy, 1997; Rainey \& Schweickert, 1991; Rainey, Schweickert, Grinto, \& Pullella, 
1990). There was a dearth of publications until the mid 2000s when Nicholson and Hoye (2005) focused predominantly on poor behaviour in Australian sport more generally, although they did consider the impact on behaviour of decisions made by inexperienced referees. More concerted coverage of the negative behaviour of stakeholders towards young match officials in football was included in the book 'Child welfare in football' (Brackenridge, Pitchford, Russell, \& Nutt, 2007) and an evaluation of the Respect Programme designed and implemented by the EFA (Brackenridge, Pitchford, \& Wilson, 2011). Research at this time was starting to consider the impact on the match officials more widely, with concepts related to stressful experiences in ice hockey considered, although this was from a psychological disciplinary perspective (Dorsch \& Paskevich, 2007).

From approximately 2007, management related research has tended to focus on the topic of abuse and aggression towards match officials, and why this abuse might have occurred. Moreover, other factors such as support have also been identified in the management related literature as an important matter to consider when related to the discontinuation of match officials. Kellett \& Shilbury (2007) discovered that socialisation as part of officiating was important to practicing Australian Rules football umpires, and that abuse is often reframed to be considered as part of the role of a match official. Moreover, Kellett and Warner (2011) subsequently considered how the social interactions of umpires can contribute toward their retention in sport and, crucially, what aspects of these relationships and the related factors, detract from a sense of community, leading to thoughts of discontinuation. Related research has also focused upon the motivation and intention of match officials to continue in their chosen sport (Cuskelly \& Hoye, 2013; Giel \& Breuer, 2019).

Recently academic attention has been focused specifically on the abuse to which match officials are subjected across various sports, such as football, rugby union, cricket and 
rugby league in England (Cleland et al., 2017; Webb et al., 2017; Webb, Rayner, \& Thelwell, 2018). In research emanating from the United States of America contributions have centred around any constraints around the retention of match officials, how and why these match officials continue in their chosen sport and what governing bodies might do in order to improve their discontinuation rates (Ridinger, 2015; Ridinger, Kim, Warner, \& Tingle, 2017a; Ridinger, Kim, Warner, \& Tingle, 2017b; Tingle, Warner, \& Sartore-Baldwin, 2014; Warner, Tingle, \& Kellett, 2013). Research from South Korea has focused on female referees in South Korean football, evidencing the growing interest and reach of the subject area (Kim \& Hong, 2016; Min-Chul \& Eunah, 2016). Studies have also begun to consider some of the concepts related to the abuse of match officials and their discontinuation across different countries, in order to determine whether trends exist across geographical borders (Webb, Dicks, Thelwell, van der Kamp, \& Rix Lievre, 2020).

Despite the advancement in the academic research, particularly over the past 10-15 years, there are still significant gaps in the coverage of this literature and hence, the understanding of some of the complex interactions between the major stakeholders involved in sport at many levels of the game, namely, the match officials, the players, the coaches and the spectators. This commentary now turns its attention to these gaps and the areas for future research considered the most prevalent in the forthcoming years.

\section{Where next?}

The growth in the sports match official literature has seen increased understanding of the challenges faced by this often-marginalised group (Webb et al., 2020). Nevertheless, there are gaps in the literature and there are some emerging areas of research which require greater coverage in this developing subject area. We can see that our understanding of abuse is developing rapidly. However, the extant research focuses predominantly on the on field or pre/post-match experiences of match officials in their face to face interactions with players, 
coaches and spectators. We know little about the online, social media world that match officials, players, coaches and spectators inhabit before and after fixtures take place. Scholarly activity has occurred regarding the interactions that people have on social media, and some valuable work exists related to sport in this arena and the vitriol that can exist in online communities (Jane, 2014; Kavanagh \& Jones, 2016; Kavanagh, Jones, \& SheppardMarks, 2017; Sanderson \& Truax, 2014). Authors should be encouraged to consider the notion of match official abuse through an online, social media lens. As our society evolves, and technology becomes even more prevalent than it is today, these social media related interactions will become more frequent. It is therefore important to understand this subject area, not least to instigate and facilitate any involvement from governing bodies in this area.

Similarly, it is also imperative to consider the abuse of match officials from other perspectives. Much of the existing research considers the experience of the match official themselves, and whilst this is valuable and important to understand, we do not have as detailed coverage of the views and actions of coaches, players and spectators in these relationships. To date scant research has been conducted in this area, with one empirical study recently published concerning the views and perceptions of referee abuse from rugby union coaches (Jacobs, Tingle, Oja, \& Smith, 2020). Nevertheless, the views of players, coaches and spectators and their reasons for exhibiting negative behaviour, or resorting to abusive actions towards match officials, offer another view of match official abuse, and further understanding in this area would provide more coverage of the subject and would also inform decisions and interventions by governing bodies.

Inextricably linked to the action of abuse is the notion of mental health. If a match official is subjected to verbal or physical abuse, there could be an ongoing negative impact on that match official. Clearly any impact is dependent on individual tolerance levels and personal wellbeing (Voight, 2008), as well as the severity of the abusive incident, however, 
to date we do not understand the consequences of this abuse on the individual mental health of match officials. Governing bodies are beginning to provide some mental health assistance for match officials (The FA, 2020). Nevertheless, the wellbeing of match officials across sport should be of paramount importance, given the concerns regarding recruitment and retention that have been discussed in this commentary. To date research in this area is sparse, particularly related to the impact of abusive occurrences upon match officials. One study has considered symptoms of common mental disorders amongst 391 professional football referees in Europe, during the 2015-16 season (Gouttebarge, Johnson, Rochcongar, Rosier, \& Kerkhoffs, 2017). The research identified that referees self-reported common mental disorders, with anxiety/depression, sleep disturbance, eating disorders and adverse alcohol use all identified (Gouttebarge et al., 2017). This work focused upon elite referees and the challenges faced at this level and given that verbal and physical abuse are less prevalent in professional football (Webb, Rayner, Cleland, \& O’Gorman, in press), abuse was not a consideration of this study. As a result, research concerning mental health and wellbeing with large populations of match officials across different sports and officiating levels should be encouraged in quantitative focused studies, and in qualitative approaches with smaller groups, utilising interviews or focus groups to obtain detailed experiential information.

Finally, specific and targeted research with young and female match officials, should be pursued. Young match officials have specific needs and requirements in sport, and have issues with vulnerability, whereas female match officials also face unique challenges in some sports, and research with these specific populations is sparse. Studies have, in part, considered young match officials and their experiences (Cleland, O'Gorman, \& Bond, 2015; Folkesson, Nyberg, Archer, Norlander, 2002; Ridinger, 2015), although specific targeted work with this population should be further encouraged. Moreover, scholars have focused upon the experience, isolation and negative perception of female match officials, 
predominantly in football (Forbes, Edwards, \& Fleming, 2015; Kim \& Hong, 2016) although the experiences of female rugby union referees have also been considered (Baldwin \& Vallance, 2016), as have female basketball referees (Schaeperkoetter, 2017; Tingle et al., 2014) and female football referees (Nordstrom, Warner, \& Barnes, 2016) in the U.S. Nevertheless, this research has not necessarily considered the impact on the individual of any isolation or negativity towards female match officials, and further attention across different sports and countries would also be advantageous in order to gauge any sport specific or cultural trends which might exist.

\section{Conclusion}

Given the gaps in knowledge that have been identified in this commentary, there are specific areas of investigation that warrant the attention of researchers. There has been an evolving and growing sports match official related bank of literature, with a considerable amount of this literature published in the past 10-15 years. The existing literature has tended to focus on specific areas of research concerning match officials, with physiological and technical performance related approaches the most prevalent. Sport management and sociological methodologies have been less evident, and it is from these disciplines that the literature requires further attention.

Specific subject areas have been identified as potential routes for researchers in this commentary, from both sport backgrounds and those researchers potentially from clinical backgrounds, such as healthcare professions for example. Research into areas such as the growing threat of online abuse, the perspectives of coaches and players towards the abuse of match officials, the mental health of match officials following abusive situations and working with specific groups such as female match officials and young, vulnerable match officials are all areas of enquiry that would benefit from the attention of academics. Nevertheless, any development in the research coverage should be aimed at improving the working 
environment for match officials, irrespective of the sport or country. In order to achieve this, further engagement with governing bodies is required, and some initiation of these links between academics and those individuals operating in positions of governance in sporting organisations should be fostered, to enable any impact from academic studies to be disseminated and research findings to be maximised.

Enquiry into sports match officials and the world around them has evolved considerably in recent times. Match officials offer a rich and unique population for scholars to conduct research, and as such there are a number of potential areas of research that have been identified in this commentary. Despite the growing research base and the positive outlook for future research, match officials remain an 'outgroup' in sport (Webb et al., 2000), and therefore research is required to address some of the issues identified here and to continue the evolution of this research area.

\section{References}

Anshel, M. H., \& Weinberg, R. S. (1995). Sources of acute stress in American and Australian basketball referees. Journal of Applied Sport Psychology, 7, 11-22. https://doi.org/10.1080/10413209508406297

Baldwin, C. F., \& Vallance, R. (2016). Women referees' experiences officiating rugby union. Women in Sport and Physical Activity Journal, 24(2), 152-161. https://doi.org/10.1123/wspaj.2015-0036

Brackenridge, C., Pitchford, A., Russell, K., \& Nutt, G. (2007). Child welfare in football. London: Routledge

Brackenridge, C., Pitchford, A., \& Wilson, M. (2011). Respect: Results of a pilot project designed to improve behaviour in English football. Managing Leisure, 16(3), 175191. http://dx.doi.org/10.1080/13606719.2011.583406 
Cleland, J., O’Gorman, J., \& Bond, M. (2015). The English Football Association's Respect Campaign: The referees' view. International Journal of Sport Policy and Politics, 7(4), 551-563. https://doi.org/10.1080/19406940.2015.1088050

Cleland, J., O'Gorman, J., \& Webb, T. (2017). Respect? An investigation into the experience of referees in association football. The International Review for the Sociology of Sport, 53(8), 960-974. http://dx.doi.org/10.1177/1012690216687979.

Collins, T. (2009). A social history of English rugby union. London: Routledge.

Colwell, S. (1999). Stalking referees: Resolving refereeing problems. Singer \& Friedlander Football Review 1998-1999 Season. The University of Leicester.

Colwell, S. (2000). The 'Letter' and the 'Spirit': Football laws and refereeing in the twentyfirst century. Soccer and Society, 1(1), 201-214. https://doi.org/10.1080/14660970008721259

Colwell, S. (2001). “Public enemy no. 1!” Television, commentators and our perceptions of referees. Singer \& Friedlander Football Review 2000-2001 Season. The University of Leicester.

Cuskelly, G., \& Hoye, R. (2013). Sports officials' intention to continue. Sport Management Review, 16(4), 451-464. https://doi.org/10.1016/j.smr.2013.01.003

Dell, C., Gervis, M., \& Rhind, D. (2016). Factors influencing soccer referee's intentions to quit the game. Soccer \& Society, 17(1), 109-119. http://dx.doi.org/10.1080/14660970.2014.919275.

Dorsch, K. D., \& Paskevich, D. M. (2007). Stressful experiences among six certification levels of ice hockey officials. Psychology of Sport and Exercise, 8(4), 585-593. http://dx.doi.org/10.1016/j.psychsport.2006.06.003.

Dunning, E., \& Sheard, K. (2005). Barbarians, gentlemen and players: A sociological study of rugby football. London: Routledge. 
The Football Association. (2008). The FA's vision: 2008-2012. London: The FA.

Folkesson, P., Nyberg, C., Archer, T., \& Norlander, T. (2002). Soccer referees' experience of threat and aggression: Effects of age, experience, and life orientation on outcome of coping strategy. Aggressive Behavior, 28(4), 317-327. https://doi.org/10.1002/ab.90028

Forbes, A., Edwards, L., \& Fleming, S. (2016). 'Women can't referee': Exploring the experiences of female football officials within UK football culture. Soccer \& Society, 16(4), 521-539. https://doi.org/10.1080/14660970.2014.882829

Giel, T., \& Breuer, C. (2019). The determinants of the intention to continue voluntary football refereeing. Sport Management Review. https://doi.org/10.1016/j.smr.2019.01.005

Goldsmith, P.A., \& Williams, J.M. (1992). Perceived stressors for football and volleyball officials from three rating levels. Journal of Sport Behavior, 15, 106-118.

Gouttebarge, V., Johnson, U., Rochcongar, P., Rosier, P., \& Kerkhoffs, G. (2017). Symptoms of common mental disorders among professional football referees: A one-season prospective study across Europe. The Physician and Sportsmedicine, 45(1), 11-16. https://doi.org/10.1080/00913847.2017.1248796

Hockey ACT Umpire Handbook. (2013). Retrieved from https://hockeyact.org.au/wpcontent/uploads/2019/10/2013-HACT-umpire-handbook.pdf

Holt, R. (1989). Sport and the British. Oxford: Oxford University Press.

Jacobs, B. L., Tingle, J. K., Oja, B. D., \& Smith, M. A. (2020). Exploring referee abuse through the lens of the collegiate rugby coach. Sport Management Review, 23(1), 3951. https://doi.org/10.1016/j.smr.2019.03.004

Jane, E. A. (2014). "Your a ugly, whorish slut”: Understanding e-bile. Feminist Media Studies, 14(4), 531-546. https://doi.org/10.1080/14680777.2012.741073 
Kavanagh, E., \& Jones, I. (2016). Understanding cyber- enabled abuse in sport. In S. Carnicelli, D. McGillivray, \& G. McPherson (Eds.), Digital leisure cultures: Critical perspectives (pp. 120-134). London: Routledge.

Kavanagh, E., Jones, I. \& Sheppard-Marks, L. (2017). Towards typologies of virtual maltreatment: Sport, digital cultures and dark leisure. Leisure Studies, 35(6), 783-796. https://doi.org/10.1080/02614367.2016.1216581

Kellett, P., \& Shilbury, D. (2007). Umpire participation: Is abuse really the issue? Sport Management Review, 10(3), 209-229. http://dx.doi.org/10.1016/S14413523(07)70012-8.

Kellett, P., \& Warner, S. (2011). Creating communities that lead to retention: The social worlds and communities of umpires. European Sport Management Quarterly, 11(5), 471-494. http://dx.doi.org/10.1080/16184742.2011.624109.

Kim, M., \& Hong, E. (2016). A red card for women: Female officials ostracized in South Korean football. Asian Journal of Women's Studies, 22(2), 114-130. https://doi.org/10.1080/12259276.2016.1168156

KNVB. (n.d.a). Noodnummer en nazorg bij geweld op het veld. Retrieved from https://www.knvb.nl/assist/assist-scheidsrechters/wedstrijdinformatie/noodnummeren-nazorg

KNVB. (n.d.b). Aanpak halt en knvb. Retrieved from https://www.knvb.nl/assist/assistbestuurders/verenigingsbeleid/sportiviteit-en-respect/aanpak-halt-en-knvb Malcolm, D. (2001). "It's not cricket": Colonial legacies and contemporary inequalities. Journal of Historical Sociology, 14(3), 253-275. https://doi.org/10.1111/14676443.00146 
Min-Chul, K. \& Eunah, H. (2016) A red card for women: Female officials ostracized in South Korean football. Asian Journal of Women's Studies, 22(2), 114-130. https://doi.org/10.1080/12259276.2016.1168156

National Association of Sports Officials. (2019). 2019 sports officials legislative scorecard. Retrieved from https://www.naso.org/resources/legislation/sports-officials-legislativescorecard/

Nicholson, M., \& Hoye, R. (2005). Contextual factors associated with poor spectator behaviour. Managing Leisure, 10(2), 94-105. https://doi.org/10.1080/13606710500146175

Nordstrom, H., Warner, S., \& Barnes, J. C. (2016). Behind the stripes: Female football officials' experiences. International Journal of Sport Management and Marketing, 16(3), 259-279. http://hdl.handle.net/10342/5824

Pina, J. A., Passos, A., Araújo, D., \& Maynard. T. M. (2018). Football refereeing: An integrative review. Psychology of Sport and Exercise, 35, 10-26. https://doi.org/10.1016/j.psychsport.2017.10.006

Rainey, D. W. (1994). Assaults on umpires: A statewide survey. Journal of Sport Behavior, $17,148-155$.

Rainey, D. W. (1995). Stress, burnout, and intention to terminate among umpires. Journal of Sport Behavior, 18, 312-323.

Rainey, D. W., \& Cherilla, K. (1993). Conflict with baseball umpires: An observational study. Journal of Sport Behavior, 16, 49-59.

Rainey, D. W., \& Hardy, L. (1997). Ratings of stress by rugby referees. Perceptual and Motor Skills, 84, 728-730. https://doi.org/10.2466/pms.1997.84.3.728 
Rainey, D. W., \& Schweickert, G. (1991). Evaluations of umpire performance and perceptions of appropriate behavior toward umpires. International Journal of Sport Psychology, 22, 66-77.

Rainey, D. W., Schweickert, G., Grinto, V., \& Pullella, J. (1990). Fan's evaluations of major league baseball umpires' performances and perceptions of appropriate behavior toward umpires. Journal of Sport Behavior, 13, 122-129.

The RFU. (n.d.). Keep your boots on. Retrieved from https://keepyourbootson.co.uk

Ridinger, L. L. (2015). Contributors and constraints to involvement with youth sports officiating. Journal of Amateur Sport, 1(2), 103-127. http://dx.doi.org/10.17161/jas.v1i2.4946.

Ridinger, L. L., Kim, K. R., Warner, S., \& Tingle, J. K. (2017a). Development of the referee retention scale. Journal of Sport Management, 31(5), 514-527. http://dx.doi.org/10.1123/jsm.2017-0065.

Ridinger, L. L., Warner, S., Tingle, J. K., \& Kim, K. R. (2017b). Why referees stay in the game. Global Sport Business Journal, 5(3), 22-37. http://www.gsbassn.com/Journal/Vol5-3/GSBJ-Vol5-Iss3-Ridinger-pp22-37.pdf

Sanderson, J., \& Truax, C. (2014). "I hate you man!": Exploring maladaptive parasocial interaction expressions to college athletes via Twitter. Journal of Issues in Intercollegiate Athletics, 7, 333-351.

Schaeperkoetter, C. C. (2017). Basketball officiating as a gendered arena: An autoethnography. Sport Management Review, 20(1), 128-141. https://doi.org/10.1016/j.smr.2016.05.001

Taylor, M. (2008). The association game: A history of British football. Harlow: Longman. 
Tingle, J. K., Warner, S. \& Sartore-Baldwin, M. L. (2014). The experience of former women officials and the impact on the sporting community. Sex Roles, 71(7-20). https://doi.org/10.1007/s11199-014-0366-8

Vamplew, W. (1988). Pay up and play the game: Professional sport in Britain 1875-1914. Cambridge: Cambridge University Press.

Voight, M. (2008). Sources of stress and coping strategies of US soccer officials. Stress \& Health, 25(1), 91-101. https://doi.org/10.1002/smi.1231

Warner, S., Tingle, J. K., \& Kellett, P. (2013). Officiating attrition: The experience of former referees via a sport development lens. Journal of Sport Management, 27(4), 316-328. http://dx.doi.org/10.1123/jsm.27.4.316.

Webb, T. (2017). Elite soccer referees: Officiating in the Premier League, La Liga and Serie A. London: Routledge.

Webb, T., Cleland, J., \& O'Gorman, J. (2017). The distribution of power through a media campaign: The Respect programme, referees and violence in association football. The Journal of Global Sport Management, 2(3), 162-181. https://doi.org/10.1080/24704067.2017.1350591

Webb, T., Dicks, M., Thelwell, R., van der Kamp, J., \& Rix Lievre, G. (2020). An analysis of soccer referee experiences in France and the Netherlands: Abuse, conflict, and level of support. Sport Management Review, 23(1), 52-65. https://doi.org/10.1016/j.smr.2019.03.003

Webb, T., \& Gorczynski, P. (in press). The welfare, wellbeing and mental health of sports match officials: The potential impact of abuse and a destabilised support system from a global context. In M. Lang (ed), Routledge International Handbook of Athlete Welfare. London: Routledge. 
Webb, T., Rayner, M., Cleland, J., O'Gorman, J. (In press). Referees, match officials and abuse: Research and implications for policy. London: Routledge.

Webb, T., Rayner, M., \& Thelwell, R. (2018). An explorative case study of referee abuse in English Rugby League. Journal of Applied Sport Management, 10(2). https://doi.org/10.18666/JASM-2017-V10-I2-8834

Webb, T., Rayner, M., \& Thelwell, R. (2019). An examination of match official's perceptions of support and abuse in rugby union and cricket in England. Managing Sport and Leisure, 24(1-3), 155-172. https://doi.org/10.1080/23750472.2019.1605841

Webb, T., Wagstaff, C., Rayner, M., \& Thelwell, R. (2016). Leading elite Association Football referees: Challenges in the cross-cultural organization of a geographically dispersed group. Managing Sport and Leisure, 21(3), 105-123. https://doi.org/10.1080/23750472.2016.1209978 